【報告】

UDC : 711.13
日本建築学会計画系論文報告集 第 433 号・1992 年 3 月

Journal of Archit. Plann. Environ. Engng, AIJ, No. 433, Mar., 1992

\title{
国土空間の形成に係る都市化の基本的傾向に関する研究 A NATIONWIDE ANALYSIS OF GROWTH MECHANISM IN THE URBANIZED AREAS
}

\author{
春田尚 徳* \\ Hisayoshi HARUTA
}

\begin{abstract}
The urban area extends faster than the activities and population concentrate on the area owing to the technological progress in communication; Tokyo metropolitan region is estimated to cover the area with a radius of $400 \mathrm{~km}$. This tendency has recently been so accelerated that Tokyo's frontier is streching to cover the whole country. 45000 persons, including 1600 persons in Fukuoka on the west and 1900 persons in Yamagata and Iwate on the east, are commuting a long distance trip to Tokyo on the 1985 census basis.
\end{abstract}

Keywords : urbanization, nationwide scale, regional expansion, population density, Tokyo metropolitan area, long distance commuting area 都市化, 国土空間, 広域化, 人口密度, 東京圈, 遠距離通勤園

\section{1. まえがき}

我が国の人口配置等国土構造は, 16 世紀以来数世紀 にわたって断続的に進行してきた都市化に伴って変動し つつ形成されてきた。長期にわたる都市化過程を通じて, 国土の利用に基礎的不均衡が蓄積し，その上に長期的対 応を要する諸問題が発生してきた。特に, 近年コミュニ ケーション技術の革命的進歩によって距離が飛躍的に短 縮し，情報化亡国際化が一体的に進み，つれて産業社会 が変わり, 都市全体が新しい発展を担いつつ国土全域に 向かって広域化し,国土空間は一体化の傾向を強める等, 都市化過程は新たな段階に直面している。

我が国における都市社会の構造変化, あるいは都市空 間の形成に関する知見の集積は膨大になるが，国土構造 あるいは国土空間にかかわる都市化の定量的研究は，人 口移動と所得格差の関係などにとどまり本格的にはなさ れてこなかった。都市化の発生と進行およびその国土空 間への展開等都市的地域全体の発展過程にかかわる動学 は，なお不明で様々なアプローチによる研究が必要な段 階にある。

この研究は, 昭和 40 年代初頭の経済審議会地域部会 報告加ら, 新全総, 首都圈第二次基本計画, 自民党都市 政策大綱, 日本列島改造論, 三全総, 四全総を経てふる さと創生に至るまで，20年にわたり職業的にかかわっ てきた国土計画の実態と系譜の中から，その実態の一部 として経済企画庁総合開発局および国土庁計画・調整局
において戦後半世紀，多岐にわたり行われてきた国土計 画関連の諸研究, 就中その系譜に属しつつ, 自ら進めて きた調查研究等を基礎資料として，人口配置等今日の国 土構造の基本的性格を形成するに至った都市化の長期的 傾向を体系的に概観整理し，その上に我が国の都市化過 程が，国土空間に展開する際のメカニ゙ズムについて国土 数值情報等を活用し, 可能な限りミクロ的基礎に遡及し て独自の分析を行った。特に，人口および生産機能が国 土全域から大都市地域へ集中する動きは，コミュニケー ション技術の継続的進歩を背景として, 同時にまた都市 的地域を, より一層のスピードで国土全域へ向けて広域 化させる動きを作り出すこと，また，この傾向は特に近 年飛躍的に働き出していることなど，国土空間の形成に かかわる都市化の基本モデルを検証しつつ，この傾向を 延長した場合に得られる我が国都市化の全体像に照らし て，現段階の正確な位置づけを図る。

\section{2.人口および生産機能の長期的集中傾向}

我が国の人口配置等国土構造を長期的観点から体系的 に整理すると”，人口增加期は都市化が進み経済が成長 する，人口安定期は都市化も経済も安定するといった長 期的傾向が観察される（図一1）。

日本列島に人間が住み出してから 1 千万人まで增えた 過程は，当初狩狑採取の場として 3 千数百万ha の国土 全域に疎放的に展開されていた生産の場が，百万ha の 


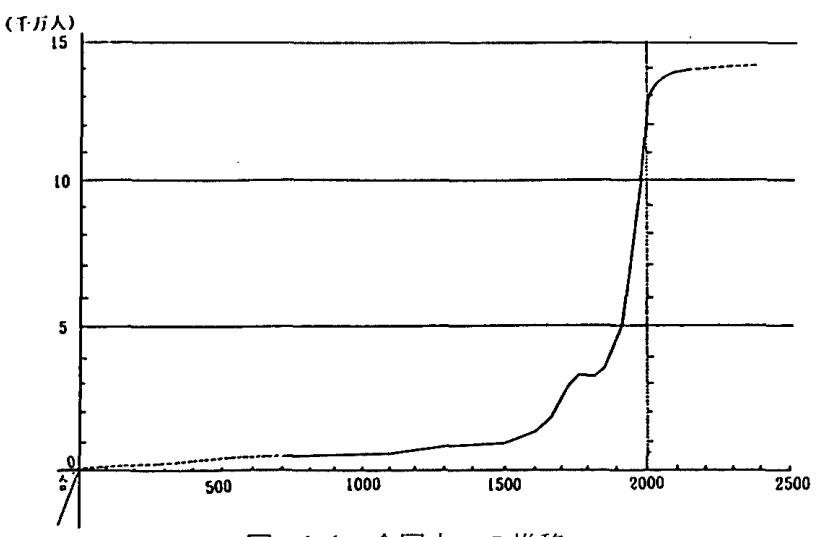

図-1-1 全国人口の推移

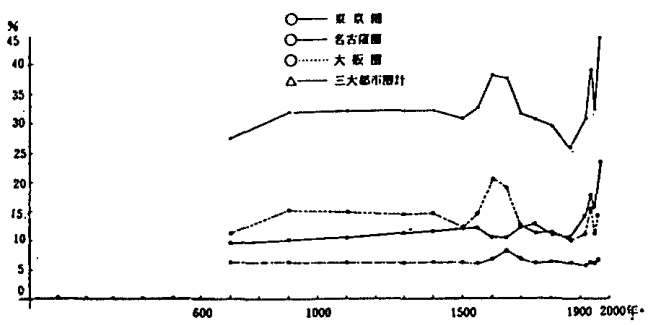

図一1-2 三大都市圈の対全国人口構成比

図一1 全国人口と都市化の長期的関係

農地に集約され限定されていく過程でもあった。

16 世紀半から，それまで 1 千万人規模であった人口 が，17 世紀にかけて 3 千万人規模に増えたが，この過 程で 100 万ha程度であった農地が 300 万 ha に増えた。 その過程で日本列島は大阪を中心に大規模な都市化を経 験し，今日の我が国の都市の多くは，まず城下町として この時代に生まれた。

その後 18〜19世紀にかけて人口は 3 干万人規模で安 定し都市化もほぼ安定する状態が続いたが，19世紀後 半から再び人口増加之都市化が始まり，100 年以上にな る。人口は 3 千数百万人から今日の 1 億 2 千万人へとや はり 3 倍になり, 東京圏の人口は 10 倍近くなった。こ れはまた，500万haの農地に代わって 20 万ha の工業 用地が生産の主力となる過程であった。そして脱工業化 が進行する今日，生産の主力は都市の中心部数万ha もう一段集約される方向にある。つまり歴史的技術革新 があるたびに生産に要する面積は一析ずつ小さくて済む ようになってきた（図一-2）。

他方，面積が縮小するのとは反対に，そこから生まれ る付加価值は桁はずれに大きくなってきた。農耕時代に あたる明治初期の経済規模は数兆円，工業化時代は数十 兆円，そして脱工業化時代初頭に当たる今日は数百兆円 である。

したがって, より少ない面積でより一層大規模な生産 活動が行われるという方向で進行する不可逆的関係が長 期的に一貫している。

以上，経済発展に伴って生産機能は国土全域からある 特定の地域,つまり結果として都市的地域となった地域,

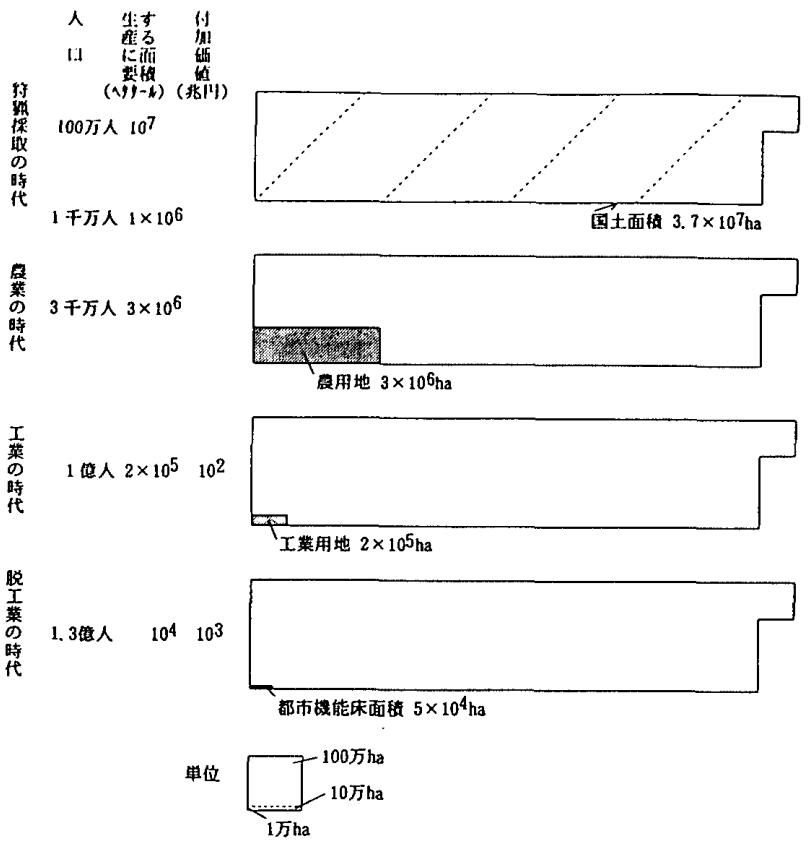

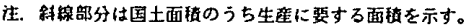

図一2 都市化-生産に要する土地の広さと人口および付加価值 の長期的関係

就中その中心へ向かって集中する長期的傾向があり，こ の傾向は有史以来一貫している。

3. 国土空間の形成にかかわる都市化の基本モデル

長期的にみて生産機能は集中傾向にあることを概観し たが，次に，他方地域空間はより一層の勢いで拡大傾向 にあるという本論文の中心課題を検証し，その長期的帰 結について考察する。

（1）都市化の進行と密度の相対関係

歴史的にみて，都市は一般に一番小さな原初の段階に おいて人口密度が最も高く，その後成長して大きくなる につれ人口密度は低下する傾向があり, 特にこの傾向は 産業革命以降顕著であると言われる2!。これは一般に都 市的地域の拡大は都市人口の増加を上回る勢いで進んで きたことを意味する。つまり，逆説的に言えば，都市化 が進むほど都市的地域の人口密度は低くなることにな る。

この考え方を我が国の都市化過程にあてはめ検証す る。都市的地域全体の傾向を見るため, 都市的地域の具 体的基準として, 国勢調查における人口集中地区 (DID) をもってとらえることとし，DIDについて人口，面積， 人口密度の関係を昭和 35 年から 60 年について整理した (表一1)。これによれば，DID 人口は，35 年の 4803 万人から，60 年には 1.5 倍の 7334 万人に増加したが， DID 面積は39 万 ha から 106 万ha と 2.7 倍に拡大した ため，DID 人口密度は 103 人/ha から 69 人/ha へと一 貫して減少傾向を示すに至った。

さらに，国土数值情報において最も詳細に地域デー夕 
表一1 人口集中地区人口密度 $\left(\right.$ 人 $\left./ \mathrm{km}^{2}\right)$

\begin{tabular}{|c|c|c|c|c|c|c|}
\hline 愐 目 L 年次 (昭和) & 35 年 & 40 年 & 45 年 & 50 年 & 55 年 & 60 年 \\
\hline & 10.563 & 10,263 & 8,690 & 7.712 & 6.983 & 6. 938 \\
\hline 果京圈' & 12,807 & 12,503 & 10,473 & 9,514 & 8.882 & 8. 971 \\
\hline 東京都 & 15. 527 & 15.242 & $\cdot 13,467$ & 12. 332 & 11,532 & 11.544 \\
\hline $\begin{array}{r}23 区 \\
278\end{array}$ & 17,377 & 17,258 & 16. 008 & . 14, 982 & 14,109 & 13, 974 \\
\hline 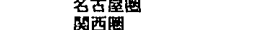 & $\begin{array}{r}9.717 \\
12.54\end{array}$ & $\begin{array}{r}9.325 \\
12.683\end{array}$ & $\begin{array}{r}7.831 \\
10.791\end{array}$ & $\begin{array}{l}6,636 \\
9.834\end{array}$ & 5,821 & 5.773 \\
\hline 三大都市国 & $\begin{array}{l}12,814 \\
12,08\end{array}$ & $\begin{array}{l}12,000 \\
12,056\end{array}$ & 10.170 & 9,034 & 8.360 & $\begin{array}{l}8.924 \\
8.378\end{array}$ \\
\hline & 8.831 & 8,280 & 6,980 & 6.070 & 5,467 & $\begin{array}{l}8,370 \\
5,379\end{array}$ \\
\hline & 12,243 & 11,970 & 10,046 & 9,012 & 8. 329 & 8.355 \\
\hline
\end{tabular}

表一2 昭和 45 年から 60 年にかけて形成された関東平野の市街 地の変容

\begin{tabular}{|c|c|c|c|c|}
\hline r & 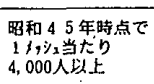 & 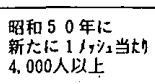 & 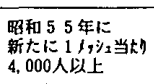 & 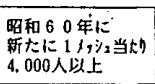 \\
\hline & $1668 \mathrm{kdd}$ & $447 \mathrm{kd}$ & 268 kid & $633 \mathrm{kdd}$ \\
\hline 昭和 45 年 & $\begin{array}{l}1780 \text { 万人 } \\
10672.0 \text { 人 } \mathrm{kd}\end{array}$ & - & - & 工 \\
\hline 昭和 50 年 & $\begin{array}{c}1826 \text { 万人 } \\
10950.9 \text { 人 } / \mathrm{kd}\end{array}$ & $\begin{array}{r}236 \text { 万人 } \\
5282.4 \text { 万人 } / \mathrm{kd}\end{array}$ & - & - \\
\hline 略和 55 年 & $\begin{array}{c}1799 \text { 万人 } \\
10788.6 \text { 人 }\end{array}$ & $\begin{array}{r}276 \text { 万人 } \\
6167.4 \text { 人 } / \mathrm{k} \text {. }\end{array}$ & $\begin{array}{l}134 \text { 万人 } \\
4988.0 \text { 万人 } \mathrm{kd}\end{array}$ & - \\
\hline 昭和 60 & $\begin{array}{r}1814 \pi / 4 \\
10875.2 人 / \mathrm{kd}\end{array}$ & $\begin{array}{r}300 \text { 万人र } \\
6713.5 \text { 人 } / \mathrm{kd}\end{array}$ & $\begin{array}{r}157 \text { 万人 } \\
5872.5 人 / \mathrm{kid}\end{array}$ & $\begin{array}{r}90 \text { 万人 } \\
4680.8 \text { 人 } / \text { kd }\end{array}$ \\
\hline
\end{tabular}

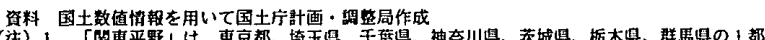

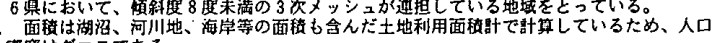
密餿はグロスである。

が整備されている 3 次メッシュ（約 $1 \mathrm{~km}$ 四方）単位の データを用い，1メッシュ当たり 4000 人以上の地域の 面積，人口，人口管度の時系列変化を求めると，昭和 45 年時点で形成された市街地の人口密度が, その後徐々 に低下している一方，50，55，600各年において新た に(そしておそらく外側に) 形成された市街地ほど低密 度になる傾问が顕著である（表一2）。

つまり，都市へ人口が集まる動きと同時平行的に，し かも人口増加を上回るより早い勢いで都市的地域を外へ 広げる動きがあり，それが都市へ人口が集まる動きと一 体であるものと考えられる。

\section{(2) 東京の広域化の推計}

このような都市的地域全体の傾向は，それぞれの都市 についてネットワークの整備が進むにつれ，狭い範囲に 高密度に集積していた諸機能が，遠心分離機にかかった かのように広範囲に分解的に振り飛ばされ再配置され， 地域空間が広く薄く広域化していく具体的過程を内包し ている。

特に上記の一般的傾向の中で，データの採り方によっ ては，昭和 55 年から 60 年にかけて，東京圈でわずかな がら例外的に稠密化が進んだとも見られることが注目さ れる(表一1)。これは, 50 年代後半の東京圈への人口 再集中や，都心部とその近傍での高層化の進行によると 考えられるが, 根本的には, 統一的まとまりのある生活 圏としての “東京”（以下，「東京圈」でも「東京区部」 とも異なる，南関東における生活圈としてのまとまりを このように表示する。）が，これまでの 1 都 3 県として の東京圏を超えて今一段広域化しつつあるからではない か。以下，分析方法に工夫を加えて検証を進める。

まず，幸田成友氏によれば，江戸の町方人口は 475
表一3. 東京から距離圈ごと人口密度の推移

\begin{tabular}{|c|c|c|c|c|}
\hline & & & & 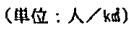 \\
\hline & 昭和 60 年度 & 昭和 55 年度 & 昭和 50 年度 & 昭和 45 年度 \\
\hline $50 \mathrm{~km}$ 圈 & 6850 & 67114 & 6798 & 6821 \\
\hline $100 \mathrm{~km}$ 圈 & 5401 & 5356 & 5415 & 5538 \\
\hline $150 \mathrm{~km}$ 圈 & 4984 & 4949 & 5014 & $\begin{array}{llll}5 & 1 & 3 & 7\end{array}$ \\
\hline $200 \mathrm{~km}$ 圈 & 4659 & 4629 & 4691 & 4804 \\
\hline $250 \mathrm{~km}$ 园 & 4369 & 4344 & 4403 & 4532 \\
\hline $300 \mathrm{~km}$ 圈 & 4134 & 4118 & 4168 & 4290 \\
\hline 350 km圈 & $4 \begin{array}{llll}4 & 0 & 1\end{array}$ & 3990 & 4042 & 4168 \\
\hline $400 \mathrm{~km}$ 圈 & 4141 & 4132 & 4188 & 4290 \\
\hline $450 \mathrm{~km}$ 圈 & 4302 & 4306 & 4384 & 4520 \\
\hline $500 \mathrm{~km}$ & 4245 & 4250 & 4318 & 4452 \\
\hline $550 \mathrm{~km}$ 圈 & 4163 & 4168 & 4236 & 4371 \\
\hline 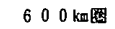 & 4086 & 4091 & 4157 & 4297 \\
\hline $650 \mathrm{~km}$ & 4042 & 4049 & 4111 & 4253 \\
\hline $700 \mathrm{~km}$ 图 & 4039 & 4043 & 4107 & 4250 \\
\hline $750 \mathrm{~km}$ & 4016 & 4022 & 4083 & 4227 \\
\hline $800 \mathrm{~km}$ 圈 & 3992 & 3999 & 4058 & 4202 \\
\hline $850 \mathrm{~km}$ & 3992 & 3999 & 4060 & 4204 \\
\hline $900 \mathrm{~km}$ 圂 & 3940 & 3942 & 3997 & 4130 \\
\hline $950 \mathrm{~km}$ 图 & 3886 & 3888 & 3940 & 4066 \\
\hline $1000 \mathrm{~km}$ & 3867 & 3871 & 3922 & 4048 \\
\hline
\end{tabular}

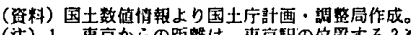

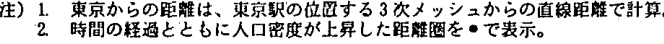

521 人 $^{31}$ (1733 年), 町地面積は 2696 千坪 (幕末) とさ れるから，町方の人密度は 534 人/ha となる。また， 石明頼房氏によれば，1840年代の町奉行の支配下人数 は 48 万人，同面積は 891 ha，したがって人口密度は 539 人/ha とされる ${ }^{4}$ 。一方，表一1に示すとおり，昭和 60 年の市街地の人口密度は都区部 140 人/ha，東京都 115 人/ha, 東京圈 90 人/haであるか.ら, 江戸時代の“東 京”は，少なくとも今日の東京の 4 倍稠密で，それが東 凉市となり，東京都となり，今日 1 都 3 県にまで成長す るに伴って一人当たりのスペースは 6 倍程度にまで拡大 したと言える。

次に，都市的地域の発展に則した“東京”の拡大状況 を，国土数值情報によってとらえることとする。都市的 地域の基準として 3 次メッシュ当たりに含まれる人口か 1000 人以上のメッシュを抽出し，さらに，メッシュご とに東京駅の属する 3 次メッシュからの直線距離を求め た後，東京駅から $X \mathrm{~km}$ 以内に位置する 3 次メッシュを 「東京から $X \mathrm{~km}$ 圏」としてアグリゲートし, 距離圏ご との人口密度を時系列的に把握する(表一 3 )。これによ れば，昭和 45 年から 55 年までは，すべての距離圏にお いて，時間の経過に従って人口密度が低下していた。し かし，55 年から 60 年の間は，東京からら $400 \mathrm{~km}$ 圏以内 に㧍いては人口密度が上昇しているが， $400 \mathrm{~km}$ 圈を超 えるとやはり低下しはじめる。先に都市的地域全体につ いて検証した一般的仮説によれば，“東京”を $400 \mathrm{~km}$ 圏までと考えたとき最近の都市的地域の人口密度が増加 し，450 km 圈と考えたとき低下しはじめるということ は，実際の “東京” は既に $400 \mathrm{~km}$ 圏と $450 \mathrm{~km}$ 圈の間 
にまで来ているものと推定される。交通, 情報通信ネッ トワークが完成に近づくにつれ, 今後この傾向は一段と 強まり，“東京” はますます薄く広く，関東平野全域か ら $400 \mathrm{~km}$ 圏に向かって広域化していくと推論される。 それどころかこの傾向は特に近年飛躍的に働きだしてお り，“東京”の先端部分は $400 \mathrm{~km}$ 圈を遙かに超えて国 土全域に迫りつつあるという驚くべき事実が以下の分析 によって明らかになる。

\section{（3）避距離通勤通学圈の全国的拡大状況の把握}

国勢調查の市区町村別データを用いて，通勤通学圈域 の㹡大状況を把握した ${ }^{5)}$ 。昭和 45, 50, 55, 60 年の各年 の国勢調查の「従業地・通学地における人口」集計にお いて, 従業地, 通学地を東京都区部とする就業者, 通学 者の常住地として就業者, 通学者の数が揭げられている 市区町村をリストアップする。さらに，市区町村ごとに， 初めて東京都区部「への」あるいは「からの」就業者, 通学者の数が掲げられた国勢調査年を整理し，日本地図 上に表示する。

この際，解析上の制約として，国勢調査においては, 就業者, 通学者が 1 人以上存在しても 10 人に満たない 場合は市区町村ごとのデータは揭載されていないこと， そして全国全市区町村間の通勤，通学流動を対象とする と調査規模が過大となるため，その時点における交通体 系等の整備状海を考慮して都道府県ごとに通勤, 通学者 数の集計の対象となる組合せを限定しており,上記の「就 業者, 通学者の数が揭げられている市区町村」は，集計 対象亡なる都道府県内にある市区町村に限られているこ と, 特に国勢調查の実施のたびに集計の範囲が拡大して きていることに留意する必要がある。

各国勢調查年における, 従業地, 通学地を東京都とす る通勤, 通学者の集計対象都道府県は以下のとおりであ る。

昭和 45 年...茨城県, 杤木県, 群馬県, 埼玉県, 千葉県, 神奈川県, 山梨県, 長野県, 岐阜県, 静 岡県, 愛知県, 京都府, 大阪府

昭和 50 年 $\cdots 45$ 年時点の調查対象に加え, 兵庫県, 岡 山県, 広島県

昭和 55 年 $\cdots 50$ 年時点の調查対象に加え, 宮城県, 福 島県, 新潟県, 三重県, 福岡県

昭和 60 年 $\cdots 55$ 年時点の調查対象に加え, 岩手県, 山 形県，奈良県

また，上記の調查対象範国拡大の根拠となったと考え られる, 高速交通体系の整備状況の概略は以下のとおり である。

- 昭和 39 年…東海道新幹線 東京一大阪開業

昭和 47 年.. .4 陽新幹線 大阪一岡山開業

昭和 50 年…山陽新幹線 岡山 博多開業

昭和 57 年…東北新幹線 大宮一盛岡開業

\section{" $\quad \cdots$ 上越新幹線 大宮～新潟開業}

- 昭和 44 年...東名 - 名神高速道路 東京一神巨供用 昭和 50 年…中国縦貫自動車道 大阪一美作供用

" $\quad \cdots$ 東北縦貫自動車道 岩槻〜仙台供用 昭和 54 年…東北縦貫自動車道 仙台一盛岡供用 昭和 55 年…中国縦貫自動車道 全線供用 したがって厳密に言えば，「初めて就業者，通学者が揭 げられた国勢調查年」をもって直ちに当該市区町村が東 京の通勤, 通学圈になったとするのは不正確である。そ れ以前にも, 調查対象都道府県以外からの通勤, 通学者 が存在するかもしれないからである。しかしながら，調 查当局が集計範囲の拡大を行ったのは，上記のとおり， 既に交通体系等の整備に伴う通勤, 通学流動の広域化が はっきりと認識されているためであり，このような作業 で得られる知見は，極めて少数の例外どころか，ある程 度以上定着した動きともとらえることができる。これを 踏まえ,ここでは, 便宜的表現として, 「初めて就業者, 通学者が揭げられた国勢調查年」をもって当該市区町村 が東京の通勤, 通学圈域となった時点とする。

以上の点に留意しつつ, 作業の結果を図一 3 , 図一 4 に示す。昭和 60 年時点で, 東京圏辺の 1 都 4 県 (東京都, 埼玉県, 千葉県, 神奈川県, 茨城県) を除く国土全域か ら約 45000 人が東京へ，そして逆に 9400 人が東京から 地方へ遠距離通勤している姿が浮かんでくる。特に，西 端では福岡県に居住する 1600 人が，東端は岩手県から 山形県にかけて居住する 1900 人が東京へ通勤, 通学し ていることになる。

国勢調查のデータは，基本的に調查対象者の回答に基 ゔくものであるから, どのような勤務, 通学の形をとっ ているにせよ, これだけの人々が, 福岡や岩手, 山形を 基本的な生活の根拠地としながらも，自分は東京で就業 していると認識していることになる。

そこで, これらの遠距離通勤, 通学者の奏態にもう少 し迫るために, 通勤者の職業構成を見ると, 遠距離通勤 者の中に運輸・通信従業者の占める割合が高い（広島県 で $80 \%$ ，岡山県で $84 \% ）$ が，それ以外の専門的・技術 的職業や管理的職業従業者にも一定数の遠距離通勤者の 存在が注目される。

さらに, 昭和 55 年から 60 年にかけての各県から東京 区部への通勤, 通学者数の変化をみると, 福岡県〈55 年 1548 人 $\rightarrow 60$ 年 1600 人, 以下同様), 兵庫県 (2569人 $\rightarrow 3056$ 人), 大阪府 (1956人 $\rightarrow 2680$ 人), 京都府 $(652$ 人 $\rightarrow 850$ 人), 宮城県 (2045人 $\rightarrow 2128$ 人)など東京都か ら遠距離の府県において通勤, 通学者数の増加が見られ る。これは，上で触れたようなデータ上の制約にもかか わらず, 明らかに, 通勤, 通学圈域が拡大しているもの ととらえることができよう。

以上見てきたように，東京の通勤圏は国土全域に広が 


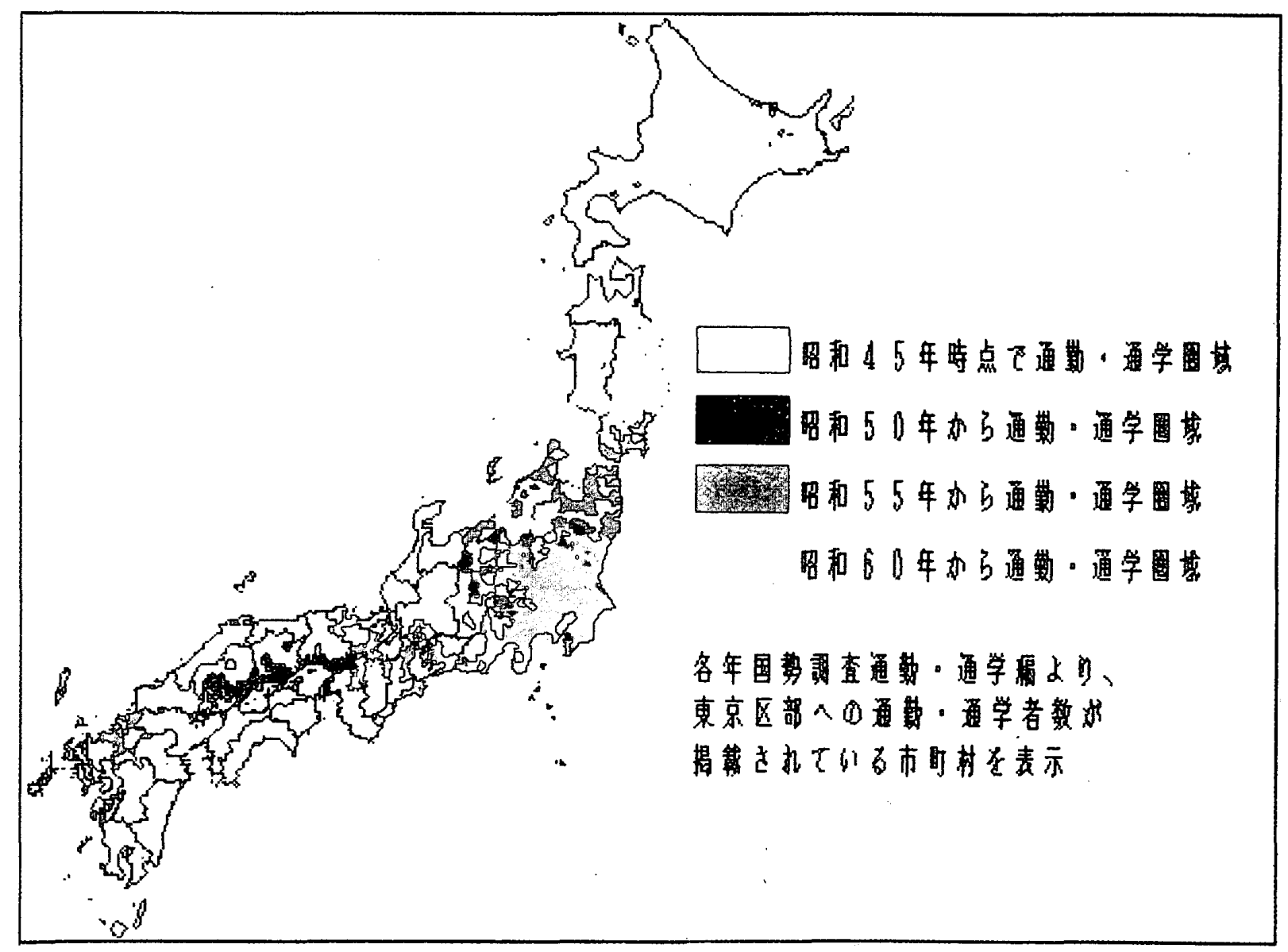

図一3 東京区部への通勤・通学圈域の拡大

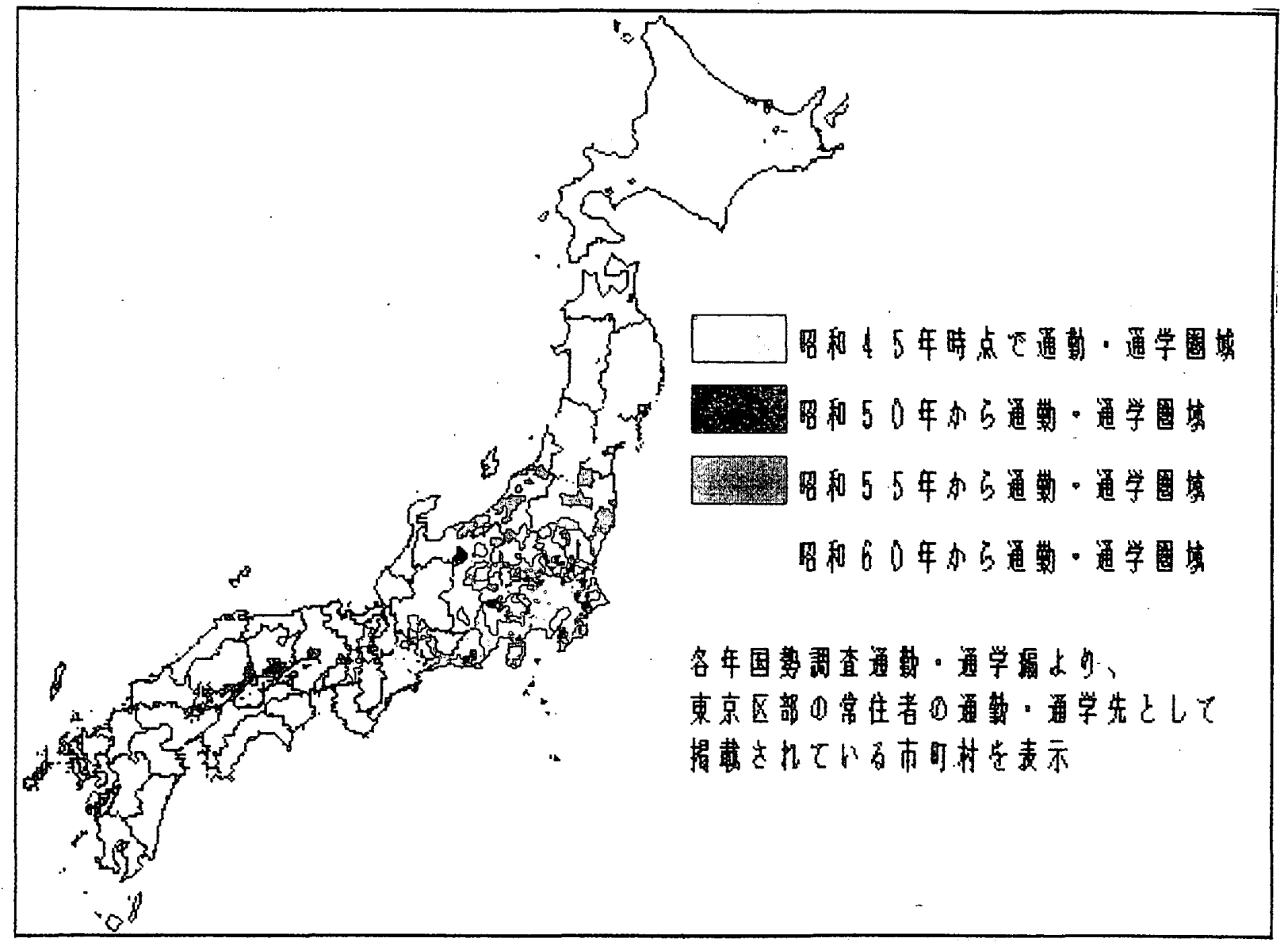

図-4 東京区部からの通勤・通学圈域の拡大 
る勢いである。まさに事実は認識を超えている。

（4）都市化の全体像亡現段階

このような傾向が継続すると, 今後, 100 年程度で関 東平野の人口は 5400 万人に増加し, 全域が市街化され る一方, その人口密度は 42 人/ha まで低下する計算に なる。

また国勢調查を始めた 1920 年以来の都市化の傾向を

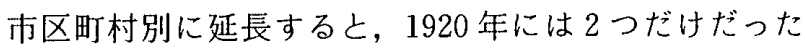
100 万都市が 2000 年で 12 都市, 2100 年には 27 都市に 増加する一方，1920 年には 2 村あったものの今日では 見られなくなった人口 100 人未満の町村が 2100 年には 496 も出現する計算になる。

つまり，2050年あるいは 2100 年といった長い目でみ ると, 東京を中心とする都市的地域つまり東京の生活圈 は関東平野を超え，400 km 圈を超え，広く薄く日本全 域に広がっていく。百年単位で考えれば東京が日本全体 になる。ということは同時にまた東京の消滅でもある。 20 世紀の大都市の特性は依然残るが，その動き自体が コミュニケーション技術の発達によって，人々がもと住 んでいた地方の都市化を進め, 人々を再びその方向へつ れ戻す運動をつくり出している。今私達はこのような長 期的変化の過程にいることになる。

\section{4. 結 語}

以上，技術革新によって生産機能が知識集約化しつつ 特定地域に集約され，少ない面積でできるだけ自然を污 さずに高い付加価値をあげられるようになる長期的傾向 があり，それによって一人当たり生産性も向上し人々の 暮らしは豊かになるが，このためには人々は集まって住 まざるをえないから，この傾向は同時に人々がより集中 して都市的地域を形成する動きと一体のものである。

つまり経済発展が長期的に可能になったのは大きな都 市の組織化が可能になったからであり，大きな都市が可 能になったのはコミュニケーション技術の進歩によって 生活圏の拡大が可能になったからである。ネットワーク が整備されるにつれ，狭い範囲に集積していた諸機能が 遠心分離機にかけられたかのように広範囲へ分解的にふ りとばされ再配置され，地域空間は広域化していく。し かもその場合，都市は集中する勢いよりも一層早いス
ピードで外側へ拡大しているから，一人当たりのスペー スは少しづつ広くなってきている。

以上，技術革新は不均衡を拡大する力と不均衡を緩和 しようとする力とを同時に創り出してきた。それでもこ れまではコミュニケーション技術が相対的に未発達で, 生産空間と居住空間を国土空間的スケールで大きく分離 できなかったため，都市的地域は極めて特定の地域に限 られていた。

ところが，今日の技術革新は人間の歴史を左右してき た主要因ともいうべきコミュニケーション技術的を中心 として起こっているため, 集中を上回る勢いで拡大する 傾向が際立つ。1980年代に至って，世界的規模で進行 する技術革新を背景に生産空間が一段と集約される一 方，コミュニケーション技術の発達もようやく生産と生 活を国土空間的スケールで分離できる段階に至ったた め, 生産機能の都心への一層の集中と居住機能の国土全 域へ向けての分散傾向とが，同時併行的に進行するとい うメカニズムが飛躍的に働く新しい段階が始まったので ある。

\section{謝 辞}

本論文は東京大学伊藤 滋教授, 名古屋大学柳沢 忠 教授から御指導をいただいた。また資料の整理などに高 津定弘，名執 潔, 越智昌之の協力をえた。印して深く 感謝の意を表する。

\section{参考文献}

1）国土仃計画・調整局：長期屡望（西暦 2000 年）作業参考 資料集，昭和 51 年，資料第三次全国総合開発計画，国土 計画協会, 昭和 52 年

2) Toynbee, A. : Cities on the Move, Oxford Univ, Press, 1970

3）幸田成友：江戸の町人の人口，社会経済史学，第 8 巻, 第 1 号

4）石田頼房：近代都市計画の百年，自治体研究社，昭和 62 年

5）春田尚徳：国土構造の長期変動に係る都市化の研究, 東 京大学学位論文, 平成 3 年 1 月

6） H. G. ウェルズ：世界史概観，岩波書店，1966

(1991 年 8 月 1 日原稿受理, 1992 年 1 月 8 日採用決定) 